\title{
1. The developing role of the European Ombudsman
}

\section{Herwig C.H. Hofmann}

\section{THE EUROPEAN OMBUDSMAN - BACKGROUND}

The European Ombudsman (EO) as established by the Treaty of Maastricht is entrusted with the objective of combatting maladministration by the executive branch of the European Union (EU). ${ }^{1}$ The EO's mandate and powers are Union-specific but were developed against the development of ombuds-review in various jurisdictions since the early $19^{\text {th }}$ century.

The European concept of an ombudsman was first developed in Sweden. Swedish constitutional legislation of $1809^{2}$ created an ombudsman as representative of citizens' interests, who, in the absence of direct remedies against the Swedish crown, was authorized to take cases against public authorities to court on behalf of individuals. ${ }^{3}$ In the twentieth century the idea of an independent ombudsman spread to many other jurisdictions. The concept of ombuds-review has since been adapted to a variety of different situations, such as public bodies adjudicating conflicts between individuals and certain sectors of public-interest industries, like insurance, or between minorities and the central government. ${ }^{4}$ But today's EO is

1 The EO now has its legal basis in Article 228 of the Treaty on the Functioning of the European Union (TFEU).

2 The års regeringsform of 1809. See further: Hans Gammeltoft-Hansen, 'The Establishment of the European Ombudsman', in European Ombudsman (ed.), The European Ombudsman, Origins, Establishment, Evolution, Office for Official Publications of the European Communities (Luxembourg: 2005) 13-26 at p. 14.

3 Address of Jacob Söderman given to the conference organized at the occasion of the 20th anniversary of the Ombudsman Office in Brussels, 22 June 2015.

4 See for many such institutions the Finnish Ombudsman for Minorities (an institution established in 2001 by The Finnish Anti-Discrimination Act, www. ofm.fi); the Belgian Insurance Ombudsman ('Ombudsman pour les services des assurances Belge' set up under Article 302 of the Loi relative aux assurances of 4 April 2014, Moniteur Belge of 30 April 2014 or the Canadian Public Procurement Ombudsman (http://opo-boa.gc.ca/lrpa-rarp-eng.html). 
probably most closely modelled on the Danish ombudsman. In Denmark, the office of the public ombudsman was established in the second half of the twentieth century as a body mainly empowered to fight against maladministration in the public sector and searching together with the administration to setting things right and settle the reason for complaint from the complainant's point of view. The key characteristic is thus a 'problem-solving function' with the objective of finding amicable solutions to problems between the administration and the citizenry. ${ }^{5}$

Already in the 1970s, proposals for the establishment of a European ombudsman were made. ${ }^{6}$ These were taken up in the run-up to the Treaty of Maastricht by the Spanish government, who made the first attempt to introduce a 'European Ombudsman' as an accessible body helping to overcome the perceived distance and potential alienation felt by EU citizens from the complex administrative procedures needed for implementation of EU law.7 This ombudsperson would be in charge of reviewing all implementing activities of EU law by both EU bodies and institutions as well as Member States. ${ }^{8}$ When it appeared that the Spanish version was too broad for some Member States, the Danish government then proposed limiting the ombudsman's powers to review of EU institutions only. This was the proposition which gained majority support and subsequently entered into force with the Treaty of Maastricht.

Not by coincidence, the creation of the EO took place simultaneously with the creation of the concept of Union citizenship in the Treaty of Maastricht. In fact, the right to turn to the EO with a complaint about an instance of maladministration is quite explicitly linked to the concept

5 Address of Jacob Söderman given to the conference organized at the occasion of the 20th anniversary of the Ombudsman Office in Brussels, 22 June 2015.

6 For the history of the idea of establishing a European Ombudsman and a general overview over the office, see, e.g., Saverio Baviera, 'Les pétitions au Parlement européen et le Médiateur européen', RMC 445 (2001) 129-36; Simone Cadeddu, 'The proceedings of the European Ombudsman', $L$ \& Contemp. Probs 68 (2004) 161-80; Jacob Söderman, 'A thousand and one complaints: the European Ombudsman en route', EPL 3 (1997) 351-61; Alexandros Tsadiras, 'The Ombudsman', in Paul Craig (ed.), European Administrative Law (Oxford University Press 2006) 829-32.

7 Anne Peters, 'The European Ombudsman and the European Constitution', CMLRev. 42 (2005) 697-743 at 699-700.

8 Carlos Moreiro González, 'The Spanish Proposal to the Intergovernmental Conference on Political Union', in The European Ombudsman (ed.), The European Ombudsman, Origins, Establishment, Evolution, Office for Official Publications of the European Communities (Luxembourg: 2005) 27-37; speech by Jacob Söderman given to the conference organized at the occasion of the 20th anniversary of the Ombudsman Office in Brussels, 22 June 2015. 
of EU citizenship, in such rules as Articles 20(2)(d) and 24 (third paragraph) TFEU, pursuant to which '[e]very citizen of the Union may apply to the Ombudsman established in accordance with Article 228' TFEU. This is also explicitly protected as a fundamental right in Article 43 of the Charter of Fundamental Rights of the European Union ('Charter'), which gives citizens and persons residing in the Member States the right to refer to the 'Ombudsman cases of maladministration in the activities of the institutions, bodies, offices or agencies of the Union'.

\section{The Approach Taken by the First Three Holders of the Office of the European Ombudsman}

For the first twenty years of its existence, three individuals have held the role of the EO and each has interpreted the role's mandate a bit differently. The approach taken by the individual office holder, particularly in such a personalized body as the EO, can be - and has been - quite decisive.

The first holder of the office was the former Finish Ombudsman, Jacob Söderman. He approached the office's mandate to review EU administration activities by first finding that the EO should deal with the concerns expressed by citizens about the Commission's role as the 'Guardian of the Treaty'. However, he also interpreted the mandate of the EO broadly to include also the growing number of European agencies. This approach was officially vindicated with entry into force of the Treaty of Lisbon. Article 228 TFEU now explicitly recognises the EO's mandate to supervise actions of institutions, bodies, offices and agencies of the Union. An explicit exception exists only for the Court of Justice of the European Union (CJEU) when acting in its judicial capacity. ${ }^{9}$

Söderman's approach was further to indirectly include Member State activity by requiring the Commission to provide information to individual complainants about a Member State's violation of EU law. One of Söderman's central contributions was ensuring that the institutions respected their obligations through a careful-but-forceful review of complaints. By mostly handling individuals' complaints, he embodied the EU-legitimizing role of the defender of citizens' rights and interests in the good administration of the Union. In this context, he defined maladministration through a soft-law guidance document entitled 'The

9 Article 228(1) TFEU and Nikiforos Diamandouros, 'The European Ombudsman and the Application of EU Law by the Member States', Review of European Administrative Law 2 (2008) 5-37 at p. 7. 
European Code of Good Administrative Behaviour'. ${ }^{10}$ Despite efforts to convince the institutions to adopt the soft-law code as a binding act of the Union, no EU administrative procedure act has entered into force. Nevertheless, EO Söderman successfully lobbied for the inclusion of Article 41, entitled 'Right to Good Administration', in the Charter. On yet another front, in order to overcome the shortcomings of a mandate limited to just the institutions and bodies of the Union, EO Söderman initiated a network of ombudsmen, including national ombudsmen and similar bodies throughout the Member States, which was designed to address complaints about implementation of EU law by Member State bodies.

The second EO, the former Greek ombudsman, Nikiforos Diamandouros, placed particular emphasis on the fact that the maladministration the EO should be expected to address is a far-wider and more encompassing concept than just illegal activity on the part of EU institutions and bodies. Rather, he added to the EO's already accepted role as defender of citizens' rights and interests the additional role of 'enhancer' of the Union's integrity, which required all ombudsreview to also focus on the manner and effect of EU administrative activity. ${ }^{11}$

Twenty years after the Treaty of Maastricht entered into force, the European Parliament (hereafter, the 'Parliament') elected a third person to hold the EO office, Emily O'Reilly, a former ombudsman of Ireland. She has taken what she describes as a more 'political' approach to her role; according to her, the EO's mission should be understood as reaching well beyond a simple adjudicatory role since 'a narrow description of this institution as a complaint handling [sic] body fails ... to give adequate expression to its deeper role as an embedder of democracy, as a driver of change in a culture that still lacks the requisite levels of accountability and transparency appropriate to institutions crafted from the finest European ideals'. ${ }^{12}$

This politicization of the role of EO is an attempt to ensure more public visibility for the EO. Ombudsman O'Reilly seeks to use her office's resolution of individual complaints not only as a problem-solving tool for the individual complainants, but also as a 'driver of change'

10 See www.ombudsman.europa.eu/en/resources/code.faces\#/page/1, accessed 4 January 2017.

11 See with further explanations Nikiforos Diamandouros, Chapter 9 in this book.

12 Speech by Ombudsman Emily O'Reilly at the Conference at the occasion of the 20 years of the European Ombudsman, 22 June 2015, Brussels. 
and a 'vehicle' by which to 'tackle wider systemic problems' within the EU. ${ }^{13}$

\section{Challenges Arising from Defining the Future Role of the European Ombudsman}

The ambitious tasks formulated by O'Reilly raises the question of whether the EO's Treaty mandate allows the EO to act as a 'driver of change' and to take the initiative to actively tackle some of the EU's 'wider systemic problems' as autonomously identified by the EO. ${ }^{14}$ Is such politicization of the role of the EO and of the instrument of ombuds-review compatible with the Treaty's design and, if so, to what extent? How should the balance be struck between, on one hand, a reactive approach based on investigations of individual complaints, and, on the other, a more proactive approach based on own-initiative investigations? This chapter looks at these questions, first, by analysing the legal framework of EO activities, second, a look at the current nature of ombuds-review in the EU and, third, by an analysis of the accountability mechanism the EO faces in an attempt to answer the time-honoured question: 'quis custodiet ipsos custodes'. ${ }^{15}$

\section{THE LEGAL FRAMEWORK: THE OMBUDSMAN AS AN INDEPENDENT SUPER VISORY BODY OF THE PARLIAMENT}

The role and possibilities of ombuds-review are defined by the constitutional mandate in the Treaty provisions. These influence the notions of the EO's independence and investigatory powers and the concept of maladministration and the consequences of finding it. Although interrelated, these elements will be addressed separately in the following pages.

13 Speech by Ombudsman Emily O'Reilly given to the conference organized at the occasion of the 20th anniversary of the Ombudsman Office in Brussels, 22 June 2015.

14 Speech by Ombudsman Emily O'Reilly given to the conference organized at the occasion of the 20th anniversary of the Ombudsman Office in Brussels, 22 June 2015.

15 D. IVNI IVVENALIS SATVRA VI, at www.thelatinlibrary.com/juvenal/6. shtml, accessed 4 January 2017, line 347. 


\section{Independence and Relation to the Parliament}

The EO is a position designed to both require and protect the independence of the office holder. The nature, extent and potential of this independence define the areas in which development of the EO's activities is possible, that is to say, the potential to develop specific approaches to the office. To look for such independence, one must start with the office holder's nomination and election. Each EO must be elected by the Parliament ${ }^{16}$ 'after each election' for the duration of that particular Parliament's term of office, such that the terms of office for both the Parliament and the EO coincide. Thus, the appointment and reappointment of any particular individual to the office of EO is, to a certain degree, dependent on the political majorities in the electing Parliament.

Once elected by the Parliament, the elected individual must give his or her solemn oath, before the CJEU, to maintain his or her independence and impartiality throughout his or her term of office. Impartiality is a key term; the law requires the EO to 'be completely independent in the performance of his [or her] duties' and to 'neither seek nor take instructions from any government, institution, body, office or entity' in the performance of his or her duties. ${ }^{17}$ Consequently, to ensure the EO independence, he or she can only be dismissed by the CJEU at the request of the Parliament. Nevertheless, if an incumbent would like to be re-elected for an additional mandate, he or she might well keep an eye on the likely majorities in the next Parliament.

Post-election, the formal relationship between the EO and the Parliament consists of the EO forwarding reports to the Parliament after receiving the investigated body's or institution's response to his or her initial finding of maladministration, and presenting an annual report to the Parliament on the outcomes of his or her enquiries. ${ }^{18}$ These reports allow the Parliament, which is formally in charge of supervising the executive branch of the EU, to stay informed about maladministration and use those certain limited powers it has to force a recalcitrant administration to rectify a problem identified by the EO.

The Parliament also has a particularly strong role in designing the

\footnotetext{
16 Article 228(1) TFEU.

17 Article 228 (3) TFEU and Articles 6(2) and 9 of the Decision of the European Parliament on the regulations and general conditions governing the performance of the Ombudsman's duties, originally of 9 March 1994; (OJ 1994 L 113/15, as amended by Decisions of 14 March 2002 (deleting Articles 12 and 16) (OJ 2002 L 92/13) and 18 June 2008 (OJ 2008 L 189/25)) (hereafter, the 'Ombudsman Statute').

18 Article 228(1) TFEU.
} 
role and powers of the EO: Article 228(4) TFEU gives it the power to enact regulations and general conditions governing performance of the EO's duties, commonly referred to as the EO's 'Statute'. ${ }^{19}$ The procedure applicable to this power is unique, in that it is one of the rare occasions in which the Parliament has been given the authority to legislate on its own initiative 'after seeking an opinion from the Commission and with the approval of the Council' ${ }^{20}$

\section{Reactions to Complaints and Own-Initiative Investigations - the Ombudsman as 'Inspector of the Executive'}

The independence of the EO from executive bodies (and its link to the Parliament) is designed to permit his or her impartiality when addressing complaints about executive maladministration. Reflecting that independence, the EO is entitled to initiate an investigation either upon receipt of a complaint or on his or her own initiative.

For the former, the EO exercises his or her duties by seeking solutions to disputes between citizens, on the one hand, and EU institutions, bodies, offices, and agencies, on the other. Harden finds that '[a]lthough the focus is on the question of whether there is maladministration or not, the EO works in dispute-resolution mode, associated with the search for consensual solutions'. ${ }^{21}$

Therefore, ombuds-review contains both a review function and a redress function. This allows the EO to act, in many instances, as a cost-effective alternative to judicial redress. ${ }^{22}$ In other instances, a complaint to the EO could be the only possible redress for an individual (e.g., where

19 The Parliament exercised that power, adopting the Ombudsman Statute.

20 The legislation in force at the time this chapter was written pre-dated the Treaty of Lisbon and was adopted in the form of the Ombudsman Statute with its implementing provisions (Decision of the European Ombudsman adopting implementing provisions, 8 July 2002 as amended by decision of the Ombudsman of 5 April 2004 (hereafter, the 'Implementing Provisions')). The European Parliament is the seat of the Ombudsman (Article 13 Ombudsman Statute) which is also the seat of the Ombudsman Secretariat (Article 11 Ombudsman Statute).

${ }_{21}$ Ian Harden, 'Article 43 Ombudsman', in S. Peers, T. Hervey, J. Kenner and A. Ward (eds.) The EU Charter of Fundamental Rights (Hart 2014) 1121-50 at 1128; see also N. Diamandouros, 'The Relationship between the Principle of Good Administration and Legal Obligations', in C. Baudenbacher, C. Gulman, K. Lenaerts, E. Coulon, E. Barbier (eds.) Liber Amicorum Bo Vesterdorf (Bruylant 2007) 315-41.

22 Milan Remac, Coordinating Ombudsmen and the Judiciary (Intersentia 2014) 234-5. 
procedural errors are challenged that result in non-binding acts which are not subject to judicial review under Article 263 TFEU). More generally, ombuds-review is always subordinate to judicial review, because the EO has no power to investigate facts that 'are or have been the subject of legal proceedings' at the level of either the Union or the Member States. ${ }^{23}$

The Treaty of Lisbon introduced, in the first paragraph of Article 228(1) TFEU, a formal obligation on the part of the EO to examine complaints by individuals. After first empowering the EO to receive complaints concerning maladministration, the paragraph goes on to say that ' $\mathrm{h}] \mathrm{e}$ or she shall examine such complaints and report on them'. This last sentence leaves the EO no discretion as to whether or not to report on a complaint. Nevertheless, notwithstanding this obligation to assess a complaint, a complaint to the EO must still be admissible; the rules on the admissibility of such a complaint are outlined in the Statute, which provides, in relevant part, 'a complaint shall be made within two years of the date on which the facts on which it is based came to the attention of the person lodging the complaint' ${ }^{24}$ The assistance of the EO is subordinate to seeking 'the appropriate administrative approaches to the institutions and bodies concerned'. ${ }^{25}$ Moreover, the EO may not receive complaints that concern 'work relationships between the Community institutions and bodies and their officials and other servants unless all the possibilities for the submission of internal administrative requests and complaints, have been exhausted'. ${ }^{26}$

The right to make a complaint rests with any citizen of the Union or any natural or legal person residing or having its registered office in a Member State. ${ }^{27}$ To date, the EO has so far interpreted the Treaty's pre-conditions for access broadly: a complaint is only rejected as inadmissible if the complainant is not an EU citizen, is not physically present in the EU, or is not registered as a legal person in the EU. Questions regarding a legal person's place of registration or the existence of legal personality have been widely interpreted to include both private and public entities active in the Union. Moreover, even if a particular complainant cannot meet the strict requirements of the TFEU, the EO may, in its discretion, undertake its own investigation pursuant to Article 228(1) TFEU, as implemented

\footnotetext{
23 Article 228(2) TFEU.

24 Article 228(1) TFEU.

25 See Article 2(4) Ombudsman Statute. Moreover, complaints submitted to the Ombudsman do not affect time limits for appeals in administrative or judicial proceedings.

26 See Article 2(6) and (8) Ombudsman Statute.

27 Article 228(1) TFEU; see also Article 43 Charter, which uses the same terms.
} 
by Article 3(1) of the Statute, ${ }^{28}$ which permits the EO to review administrative activity for which an admissible complaint has not yet been, and may never be, submitted, and which may, or may not, involve European citizens. The EO's power to investigate without having received an admissible complaint ${ }^{29}$ means that the institutional scope of ombuds-review is very broad. That fact may well explain the current disconnect in the general public's perception of the EO; people do not connect the EO with European citizenship - that is to say, they have decoupled the two concepts.

Second, the EO's task is to provide supervisory oversight over the administration in general, in order to enhance its accountability and to help to improve its quality, and is thus not restricted to responding to complaints but can act on its own initiative. ${ }^{30}$ Harlow and Rawlings qualify the powers granted in Article 2 of the EO Statute to enter into own-initiative investigations as 'something of the quality of a "government inspector", standing halfway in-between administration and adjudication'. ${ }^{31}$ The EO's own-initiative investigations are not only valuable in situations where there is a public interest in clarifying and improving a situation, but also in cases where individuals are unlikely to be in a position to launch a complaint. ${ }^{32}$ His or her initiatives are a powerful tool, especially in cases where many complaints point to a more systemic problem, or in cases where individuals will generally not have the means or the know-how to complain, for example in the policy areas of immigration and asylum. The use of own-initiative investigations to overcome these specific problems, endemic in the EU system of executive governance and its multilevel administrative cooperation, appears sensible, particularly in view of the lack of other types of review available under EU law.

An own-initiative inquiry may also be launched by the EO on the basis of information provided by a so-called whistle-blower. Article

28 For an overview of the decision-making practice of the Ombudsman's office with further references, see Alexandros Tsadiras, 'The Ombudsman', in Paul Craig (ed.), European Administrative Law (Oxford University Press 2006) 833-88.

${ }_{29}$ For example, the Ombudsman may decide to start his or her own investigation after having received an inadmissible complaint or having obtained information alleging maladministration in a form that did not qualify as a complaint.

30 Anne Peters, 'The European Ombudsman and the European Constitution', CMLRev. 42 (2005) 697-743 at 711-12.

31 Carol Harlow and Richard Rawlings, Process and Procedure in EU Administration (Bloomsbury Publishing 2014) 7.

32 One such example is the Ombudsman's own-initiative enquiry OI/9/2014/ MHZ regarding types of maladministration in the context of how FRONTEX ensures, in combination with national authorities, that joint return operations are conducted with full respect for the fundamental rights of individuals. 
22a of the EU Staff Regulation, ${ }^{33}$ for example, states that officials need to report possible cases of fraud, corruption, other illegal activity, or professional conduct that constitutes a serious failure to comply with obligations, and Article $22 \mathrm{~b}$ permits, under certain conditions, those officials to provide that information to the EO. ${ }^{34}$ Even before the Treaty of Lisbon introduced a broader definition of EU administration than the one contained in the Treaty of Maastricht, the EO undertook enquiries not only into the EU institutions, but also into all 'bodies established by the Treaties. This includes the Economic and Social Committee and the European Central Bank, as well as bodies set up by legislation under the Treaties, including agencies such as the European Environment Agency and the European Agency for the Management of Operational Co-operation at the External Borders (FRONTEX). ${ }^{35}$ The EO's oversight responsibility also extends to entities that have been established jointly by the EU and one or more Member States with the aim of furthering the Union's interest (e.g., the European University Institute in Florence). ${ }^{36}$

\section{Investigative Powers of the Ombudsman}

When investigating a complaint, the EO Statute grants the EO special powers; he or she enjoys access to information and documents held by European and national administrations and may require the institutions to supply any documents within a reasonable time, conduct on-the-spot investigations, and take copies of any relevant documents found. ${ }^{37}$ Union

33 Regulation No. 1023/2013 of the European Parliament and of the Council of 22 October 2013 amending the Staff Regulations of Officials of the European Union and the Conditions of Employment of Other Servants of the European Union, OJ 2013 L 287/15-62 (hereafter the 'EU Staff Regulation'). Any such information must be provided in writing and directed to either the individual's superior, his Director-General, the Secretary General of the institution (or persons in equivalent positions), or the OLAF (Article 22a EU Staff Regulation).

34 Article $22 \mathrm{~b}$ of the EU Staff Regulation further provides that, after a certain interval has passed, the official may also provide the relevant information to, inter alia, the Ombudsman. In practice, the Ombudsman either treats the receipt of such information as a complaint or opens an own-initiative investigation on the basis of that information. For a more expansive discussion, see Ian Harden, 'Article 43 Ombudsman', in S. Peers, T. Hervey, J. Kenner and A. Ward (eds.) The EU Charter of Fundamental Rights (Hart 2014) 1121-50 at 1139.

35 European Ombudsman, Annual Report 2006, 36.

36 For example, Decision of the European Ombudsman on Complaint 659/2000/GG of 24 November 2000.

37 Article 3 Ombudsman Statute. 
institutions and bodies are obliged to supply the EO with any information he or she requests, and to provide access to files (subject to certain exceptions for classified or sensitive documents). ${ }^{38}$ At the EO's request, documents originating in a Member State are also to be provided after having informed the Member State concerned. Moreover, the EO has the power to compel Union officials and servants to testify as part of his or her investigation.

Recourse to the EO is also authorized for failure to publish information that must be published. ${ }^{39}$ The Public Access Regulation is binding on the Member States, except where national laws on secrecy or other matters prevent disclosure, and the required information is to be provided via the Member State's permanent representation. ${ }^{40}$ Where such information is not given as required, the EO is to inform the Parliament, which can then intervene itself. In addition, the EO may commission studies and hear testimony from experts external to the institutions and bodies. ${ }^{41}$ These investigatory powers, when twinned with the EO's own-initiative investigatory power, make for a particularly powerful combination. Any politically-minded EO can use these tools beyond simple reaction to complaints. Temptation might be strong to act as a supervisory agency of its own making.

\section{The Concept of Maladministration}

EO activity can, according to Article 228 TFEU, ${ }^{42}$ be undertaken 'concerning instances of maladministration in the activities of the Union institutions, bodies, offices or agencies' ${ }^{43}$ The EO has the functions of uncovering examples of 'maladministration' and 'mak[ing] recommendations to put an end to it'. The only other mention of 'maladministration' in the Treaties is in the first paragraph of Article 226 TFEU, which authorizes the Parliament to establish, without prejudice to the powers of other

\footnotetext{
38 Article 3(2) Ombudsman Statute.

39 Article 8 Regulation (EC) No. 1049/2001 of the European Parliament and of the Council of 30 May 2001 regarding public access to European Parliament, Council and Commission documents (hereinafter, the 'Public Access Regulation').

40 Article 3(3) Ombudsman Statute.

41 Article 3(2) Ombudsman Statute and Article 5(1), (2), and (4) Implementing Provisions (www.ombudsman.europa.eu/lbasis/en/provis.htm, accessed 19 February 2010).

42 See also Article 43 Charter.

43 Importantly, both Article 228 TFEU and Article 43 Charter make an exception relating to 'the Court of Justice of the European Union acting in its judicial role'.
} 
institutions or bodies, temporary Committees of Inquiry to investigate contravention or maladministration of Union law. Such Committees of Inquiry also have far reaching investigatory powers.

The concept of maladministration, although mentioned in Treaty provisions, is not defined therein. It is however, decisive to identify the EO's mandate. It is decisive for identifying the types of misconduct the EO may investigate to which the EO may offer suggestions for improvement; thus determining the term's breadth and scope is an important undertaking. According to the first EO, Jacob Söderman, the essential quality of maladministration was defined in a legal manner aligned with the Finnish and wider-Nordic traditions of ombuds-review. During his tenure, at least, maladministration was said to occur whenever an EU authority, when acting in their administrative capacity, 'fail[ed] to act in accordance with the Treaties' or with European law in general. EO Söderman believed that maladministration could equally arise out of the case law of the European courts, including the so-called General Principles of EU law expressed by the CJEU and implemented throughout the Union by national courts. ${ }^{44}$

Today, however, the EO generally looks at two main criteria to determine if an act qualifies as maladministration. The first criteria is the institution's or body's compliance with the rule of law: does the act in question respect all procedural and substantive rights of individuals including, without limitation, the individual's fundamental rights? ${ }^{45}$ In other words, the EO asks if the act or decision is legal. But, the EO's review in relation to this criteria does not extend to a review of the result of an exercise of discretionary authority undertaken within the limits of that institution's or body's specific legal authority: the EO can review the act or decision's legality but not the discretionary policy choices made by the administrative actors. ${ }^{46}$

Nonetheless, as Joana Mendes (Chapter 6 in this book) discusses, the broad nature of the EO's mandate should not, in principle, distinguish between instances of review where the administration enjoyed discre-

44 European Ombudsman, Annual Report 1997, 2.2.1. See also Peter Gjerloeff Bonnor, 'The European Ombudsman: a novel source of soft law in the European Union', ELRev. 25 (2000) 39-56 at 42-3. Jon Marcus Meese, Das Petitionsrecht beim Europäischen Parlament und das Beschwerderecht beim Bürgerbeauftragten der Europäischen Union (Lang 2000) 190.

45 See the definition of maladministration given in European Ombudsman, Annual Report 1997, 17 and 23 respectively. See generally also Paul Magnette, 'Entre contrôle parlementaire et "état de droit": le rôle politique du médiateur dans l'Union européenne', Revue Français ScPol 51 (2001) 933-48.

46 So this covers cases of what might be referred to as Rechtsaufsicht and not Fachaufsicht. 
tionary powers or not. ${ }^{47}$ Maladministration can occur in all exercise of public powers. In this view, illegality implies maladministration but is not limited to it. Focusing solely on illegality would not sufficiently distinguish the EO from an (administrative) court ${ }^{48}$ which might be regarded in violation of the effet utile of the Treaty provisions on the EO. Maladministration as a critiera takes into account the legality but not the expediency of a decision - a formal limitation of ombuds-review that should be taken into account, especially when the EO reviews discretionary decisions.

The second criteria the EO applies to determine if maladministration derives from a reflection on the very purpose of public administration: to perform administrative duties for the benefit of citizens and to enable citizens to exercise their rights. ${ }^{49}$ For example, Article 12 of the Code of Good Administrative Behaviour expressly contemplates courtesy and responsiveness by EU officials towards individuals:

The official shall be service-minded, correct, courteous and accessible in relations with the public. When answering correspondence, telephone calls and e-mails, the official shall try to be as helpful as possible and shall reply as completely and accurately as possible to questions which are asked. If the official is not responsible for the matter concerned, he shall direct the citizen to the appropriate official. If an error occurs which negatively affects the rights or interests of a member of the public, the official shall apologise for it and endeavour to correct the negative effects resulting from his or her error in the most expedient way and inform the member of the public of any rights of appeal in accordance with Article 19 of the Code. ${ }^{50}$

47 See Joana Mendes, Chapter 6 in this book. See also Gregorio Garzón Clariana, 'Holding the Administration Accountable in Respect of its Discretionary Powers', in The European Ombudsman (ed.), The European Ombudsman, Origins, Establishment, Evolution, Office for Official Publications of the European Communities (Luxembourg: 2005) 191-209.

48 For a more detailed discussion of this point, see Damien Chalmers, Christos Hadjiemmanuil, Giorgo Monto, and Adam Tomkins, European Union Law (Cambridge University Press 2006) 338.

49 In the report of the first European Ombudsman, Jacob Söderman, 'The Citizen, the Administration and Community Law' at the XVIII Congress of FIDE (Fédération internationale de droit européen), Stockholm, 3-6 June 1998 (www.ombudsman.europa.eu/fide/en/default.htm, accessed 4 January 2017) this is described in the following terms: 'At the level of national systems of administration, the principle is formulated and expressed in different ways including, for example: service-mindedness, citizen-friendliness, the citizen as "customer" and the concept of public service. The basic idea which underlies all these notions is that the administration exists to serve citizens, not vice versa.'

50 Article 12 of the Code of Good Administrative Behaviour. 
While failure to abide by these requirements does not rise to the level of illegality, it may certainly qualify as maladministration. Thus, it is a perfect example of how 'illegality necessarily implies maladministration, maladministration does not automatically entail illegality'. ${ }^{51}$ Therefore, maladministration cannot automatically be viewed as merely the opposite of 'good administration' as narrowly identified in Article 41 Charter but recognized more broadly as a General Principle of EU law. ${ }^{52}$ Although the 'good' vs. 'bad' juxtaposition sounds intuitively compelling, it does not, in fact, hold up across all language versions of the Treaty. ${ }^{53}$

The limits of the concept of maladministration are thus extremely important in identifying the EO's mandate. They arise, generally speaking, from the distinction between the processes involving legislative and judiciary functions, on one hand, and administrative action by the executive branch, on the other. This limitation indicates that the EO does not have the right to intervene when a legislative act of the Union or a court judgement requires certain action from administrations. Action taken to comply with the law is not maladministration, even though it might be understood by the complaining party - and the EO - to be 'wrongful'. ${ }^{4}$

Overall, the purpose behind the EO's mandate appears to provide some potential recourse for those actions that, while in strict compliance with the law, still result in maladministration. As courts may only sanction actions taken outside the law, the EO's role is more nuanced. It can look at the manner in which compliance occurred, and find that, while the

51 Nikiforos Diamandouros, 'The European Ombudsman and the application of EU Law by the Member States', Review of European Administrative Law 2 (2008) 5-37.

52 See Herwig C.H. Hofmann and Bucura Mihaescu, 'The relation between the Charter's fundamental rights and the unwritten general principles of EU law good administration as the test-case', European Constitutional Law Review 9 (2013) 73-101.

53 Some language versions of Articles 226 and 228 TFEU, such as the English and French language versions, speak of 'maladministration' and 'mauvaise administration', as opposed to 'good administration' and 'bonne administration', respectively. However, in other language versions (e.g., the German version), this link is less compelling, with the wording in the TFEU referring with a more limited 'Misstände bei der Anwendung [des Unionsrechts]' (Article 226 TFEU) and 'Misstände bei der Tätigkeit der Organe, Einrichtungen und sonstigen Stellen' (Article 228 TFEU), which translate more to finding a 'wrong' or 'deplorable' state of affairs rather than the notion of good administration (gute Verwaltung) in Article 41 Charter.

${ }_{54}$ See, with further examples, Ian Harden, 'Article 43 Ombudsman' in S. Peers, T. Hervey, J. Kenner and A. Ward (eds.) The EU Charter of Fundamental Rights (Hart 2014) 1121-50 at 1133. 
result was legal, it still constituted maladministration and thus the EO's mandate goes beyond what is sanctionable through judicial review. ${ }^{55}$ But, the fact that the EO can review illegality as an instance of maladministration implies that the EO has the power to interpret the law and to classify the action accordingly. This power exists independently of judicial review, which suggests that positions taken by the EO do not have to comply with those of other Union institutions. It is possible that activity categorized by the EO as illegal will not be seen as such by the CJEU, or the inverse.

Such power to interpret the law, obviously, does not change the fact that an EO recommendation is not binding. Accordingly, the aim of EO investigations can go beyond an ex post review of grievances. The EO can also draft special reports on specific concerns of maladministration and focus on specific issues in the EO's annual reports to the Parliament. This ex post review is aimed towards proactively improving administrative procedures for the future, avoiding further instances of what the EO has classified as maladministration. ${ }^{56}$ Maladministration therefore can imply unlawful conduct by an EU institution or body but maladministration can also occur where no illegality is found. ${ }^{57}$ Due to the limitations of the EO's mandate, illegality in implementation of EU law by Member State administrations can only be sanctioned by a national ombudsman, court, tribunal or equivalent. ${ }^{58}$

The nature of investigations into maladministration - with a view towards ensuring the integrity of executive action when implementing EU law - explains why the various holders of the position of the EO have consistently developed their role in a strikingly similar approach to that of the manner in which the Court of Auditors expanded the concept of auditing and, thereby, expanded its role as an oversight body. Both EU bodies see themselves as being tasked with a duty to maintain the 'integrity' of administrative decision-making and implementation of EU procedures.

55 See, e.g., T-294/03 Gibrault v Commission [2005] ECR II-635, para. 45 with clarifying reference to (Spanish language publication only); Joined Case T-219/02 and T-337/02 Herrera v Commission [2004] ECR-SC II-1407, ECLI:EU:T:2004:318, para. 101; and European Ombudsman, Annual Report 2006, 35 with references to the judgments of the CFI of 28 October 2004 in Joined Cases T-219 and 337/02 Herrera v Commission [2004] ECR-SC IA-319 and II-1407, para. 101, and of 4 October 2006 in Case T-193/04 R Hans-Martin Tillack v Commission [2006] ECR II-3995, para. 128.

56 European Ombudsman, Annual Report 2004, 9.

57 Case T-193/04 Tillack v Commission [2006] ECR II-3995, paras. 116 and 128.

58 I.G. Dimitrakopoulos, 'Is an illegal Community act necessarily an instance of maladministration, in the sense of Article 195 EC?' Review of European Administrative Law (2009) 45-55. 
Both the Court of Auditors and the EO have adopted approaches that exercise a broad contextual - and, to a certain degree, political - review of EU administrative activity. For the Court of Auditors, it started with a more encompassing standard of review, moving away from a purely financial audit towards a broader 'performance' audit. The current EO would also like to push for greater visibility and impact through high profile cases and more political activism, but the EO can only do so in the context of the EO's authority to examine instances of maladministration.

\section{Consequences of Findings of Maladministration}

If, as a result of ombuds-review, the EO finds an instance of maladministration, a number of possible steps can be taken. The effects of a finding of maladministration to a certain degree has an influence on the degree of review which the EO can, and possibly should, undertake. Once the EO finds maladministration, the next steps to be taken, and ultimate consequences, are provided for in Article 228 TFEU, Article 3(6) of the EO Statute, and Article 6 et seq. of the Implementing Provisions. ${ }^{59}$ Article 228(1) TFEU provides:

Where the Ombudsman establishes an instance of maladministration, he shall refer the matter to the institution, body, office or agency concerned, which shall have a period of three months in which to inform him of its views. The Ombudsman shall then forward a report to the European Parliament and the institution, body, office or agency concerned. The person lodging the complaint shall be informed of the outcome of such inquiries.

The Implementing Provisions go on to provide a more detailed and structured way of handling the matter. They obligate the EO, once he or she has found maladministration, to cooperate, as far as possible, with the institution or body concerned to find a 'friendly solution' to eliminate the maladministration and to satisfy the complainant. ${ }^{60}$ Friendly solution proposals typically identify shortcomings in institutional behaviour, which are often remedied in accordance with solutions proposed by the institution itself and may take the form of a sincere apology or some type of compensatory action offered to the complainant by the institution. ${ }^{61} \mathrm{In}$

59 See, generally, Simone Cadeddu, 'The proceedings of the European Ombudsman', L \& Contemp. Probs 68 (2004) 161-80.

60 See Article 3(5) Ombudsman Statute and Article 6(1) Implementing Provisions.

${ }_{61}$ European Ombudsman, 'Putting it right? How the EU institutions responded to the Ombudsman in 2013' (2014) at www.ombudsman.europa.eu/en/cases/fol lowup.faces/en/58401/html.bookmark, accessed 4 January 2017, at 5. 
principle, the idea is that the EO facilitates finding such a friendly solution. But the fact remains that the measures available to the EO have no legally binding effect vis-à-vis the institutions and bodies concerned and do not generate subjectively enforceable rights in individuals. ${ }^{62}$

Where a friendly solution is not possible or the search for such a solution did not bear fruit, ${ }^{63}$ or, in current practice, where the EO believes that such a solution would not be an effective instrument to achieve a systemic change in the public interest, the EO 'either closes the case with a reasoned decision that may include a critical remark or makes a report with draft recommendations ${ }^{64}$ to the institution concerned as to how the maladministration can be eliminated.$^{65}$ Within three months of receiving that decision or report with recommendations, the institution or body must submit its detailed opinion in response thereto ${ }^{66}$ (e.g., the institution or body may accept the EO's recommendations and describe the measures it will take (or has taken) to implement them). ${ }^{67}$ If there is no response, or the EO considers the response unsatisfactory, the EO may, but is not obligated to, draw up a special report to the Parliament, which may include recommendations; any such report must also be sent to the institution concerned and to the complainant. ${ }^{68}$ The responsibility and competence of the EO is, thus, purely recommendatory; he or she has no power to order the offending institution or body to take rectifying action in the face of a finding of maladministration and his or her decisions do not bind any other EU actors (e.g., the Parliament or the CJEU).

Despite this, levels of complaints are steady. According to the EO's annual reports, the majority of complaints received by the EO are brought by individual citizens ( 87 per cent of all complaints in 2014). ${ }^{69}$ This contrasts with the CJEU, before which the majority of plaintiffs in direct

62 Order of the CFI in Case T-103/99 Associazione delle cantine sociali venete v European Ombudsman and European Parliament (ACSV) [2000] ECR II-4165, paras. 47-50; Andreas Hamers, Der Petitionsausschuss des Europäischen Parlaments und der Europäische Bürgerbeauftragte - zu den außergerichtlichen Beschwerdeeinrichtungen der Europäischen Gemeinschaft (Pfaffenweiler: Centaurus 1999) $174-5$.

${ }_{63}$ Article 6(3) Implementing Provisions.

${ }^{64}$ Article 6(3) Implementing Provisions; see also Article 3(6)-(7) Ombudsman Statute.

${ }_{65}$ Critical remarks may only be included in accordance with Article 7 Implementing Provisions.

${ }_{66}$ Article 8(2) Implementing Provisions.

${ }_{67}$ Article 8(3) Implementing Provisions.

68 Article 8(4) Implementing Provisions.

69 European Ombudsman, Annual Report 2014, 17. 
actions are legal persons. The overall number of new complaints, which were higher immediately after Union enlargement in 2004, has stabilized and now remains relatively steady. The first few years after Union enlargement in 2004 saw the highest number of complaints. ${ }^{70}$ Since then the number of new complaints has consistently hovered around $2,100 .^{71}$ Moreover, consistently year over year, the percentage of admissible new complaints has remained at about 33 per cent. In 2014, for example, the EO launched 325 complaint-based investigations; the remaining 17 were own-initiative investigations. According to the EO, roughly onethird of the admissible cases have been settled by what the EO refers to as 'friendly' solution, i.e. without a formal report drafted by the EO. ${ }^{72}$ Overall, however, the number of complaints to the EO appears rather low, considering a Union of over 500 million citizens and countless legal persons engaged in business therein.

An important difference between the EO's investigation (followed by a finding of maladministration) and judicial review offered by EU courts is that the EO has the power to, and regularly does, investigate the relevant institution's or body's follow-up compliance with her or his recommendations. The power to do so arises from the power to investigate complaints and make recommendations as well as produce reports to Parliament. Part of the complaint handling mandate is to see the solution of the issue through to its end. In fact, the EO tracks such compliance on a case-bycase basis and keeps statistical records thereof. ${ }^{73}$ Where the EO finds cases of maladministration these are in fact regularly closed with some form of 'critical' or 'further' remarks by the EO.${ }^{74}$ According to a report commissioned by the EO in 2013 on the follow-up of the institutions and bodies of the Union to EO findings, the rate of what the report calls 'satisfactory follow-up' by the Union bodies and institutions 'critical' and 'further' remarks was above 80 per cent: 'The follow up to further remarks was

70 There were 3,920 new complaints in 2005 and 3,830 in 2006 (European Ombudsman, Annual Report 2006, 40); 3,406 in 2008 (European Ombudsman, Annual Report 2008, 37); and 3,098 in 2009 (European Ombudsman, Overview Report 2010, 5). In 2010, the number of complaints dropped to 2,667 (ibid.).

71 European Ombudsman, Annual Report 2014, 17.

72 European Ombudsman, Annual Report 2014, 17.

73 European Ombudsman, 'Putting it right? How the EU institutions responded to the Ombudsman in 2013' (2014) at www.ombudsman.europa.eu/en/cases/fol lowup.faces/en/58401/html.bookmark, accessed 4 January 2017, at 5.

74 European Ombudsman, 'Putting it right? How the EU institutions responded to the Ombudsman in 2013' (2014) at www.ombudsman.europa.eu/en/cases/fol lowup.faces/en/58401/html.bookmark, accessed 4 January 2017, at 5. 
satisfactory in 83 per cent of cases, whilst the rate of satisfactory follow up of critical remarks was 78 per cent. ${ }^{9} 7$

The EO does not always limit his or her recommendations to those necessary to rectify the individual case. Rather, when he or she deems it appropriate, the EO may include recommendations for procedural changes, and even legislative changes, to prevent similar complaints in the future. For example, he or she might recommend that the institution should provide awareness or other staff training; redesign its internal procedures; or seek legislative changes to allow it to function better.

\section{Distinguishing Ombuds-review from Judicial Review and Other Forms of Oversight}

The definition of maladministration can result in overlaps between ombuds-review, administrative review, and judicial review. Some forms of specific administrative oversight with which potentially the mandate of the EO can collide include the European Data Protection Supervisor (EDPS) overseeing privacy and data protection by EU institutions and bodies and the European Commission anti-fraud office, OLAF, which has a broad, general supervisory mandate, which in the context of investigations of wrongdoing within the EU's administration can also cover instances of maladministration. ${ }^{76}$ In fact, if the EO considers that certain facts have criminal law implications, he or she is obliged to inform the competent national authorities and, if appropriate, the OLAF. ${ }^{77}$

Overlapping responsibilities can cause duplication, inefficiency, confusion, and even divergent approaches to identical or similar issues. For example, the case Commission v Bavarian Lager ${ }^{78}$ led to a Memorandum of Understanding (MoU) between the EDPS and the EO that establishes and coordinates their approaches to data protection and access-to-document rights. ${ }^{79}$ Nevertheless, the EU's independent supervisory bodies, including

75 European Ombudsman, 'Putting it right? How the EU institutions responded to the Ombudsman in 2013' (2014) at www.ombudsman.europa.eu/en/cases/fol lowup.faces/en/58401/html.bookmark, accessed 4 January 2017, at 7.

${ }_{76}$ Regulation (EU, Euratom) No. 883/2013 of the European Parliament and of the Council of 11 September 2013 concerning investigations conducted by the European Anti-Fraud Office (OLAF) and repealing Regulation (EC) No. 1073/1999, OJ 2013 L 248/1.

77 Article 4(2) Ombudsman Statute.

78 Case C-28/08 P Commission v Bavarian Lager [2010] ECR I-6055, ECLI:EU:C:2010:378.

79 European Ombudsman/European Data Protection Supervisor, Memorandum of Understanding between the European Ombudsman and the 
the EO, are typically subject to a statutory prohibition against taking instructions from anyone in connection with their duties. Thus, the MoU between the EDPS and the EO, in which the latter 'envisages' taking the views of the EDPS concerning the correct interpretation and application of data-protection laws into account, probably reflects the outer boundary of self-limitation for the EO and all similarly situated bodies.

Regardless of the existence of agreements like the MoU, pre-existing arrangements will generally not be able to provide a complete solution to jurisdictional overlap, especially in situations in which multiple enquiries are simultaneously under way. ${ }^{80}$ There are, thus, good arguments for having a central registry for recording all complaints currently or previously subject to investigation and all own-initiative investigations by all supervisory bodies. This would allow parties as well as institutions to be able to discover parallel concerns and coordinate efforts. Therefore, any such registry should be made available for inspection by all relevant authorities, subject to appropriate safeguards. ${ }^{81}$

Moreover, some argue that, despite the potentially counter-productive lack of consistency in their respective decision, duplicative or overlapping enquiries by different independent bodies may not be all bad. ${ }^{82}$ Ultimately, the different enquiries may lead to an overall higher level of protection against maladministration and other administrative improprieties and to the achievement of the EU's goal of good administration, as different constituencies will be served. The type of complaints received by the EO differ from complaints made to other supervisory bodies and the courts. Not all matters subject to complaint before the EO are also eligible for judicial review before the CJEU.

European Data Protection Supervisor (2007/C 27/07), OJ 2007 C 27/21, illustrates the dangers involving the interaction of various supervisory bodies. Commission $v$ Bavarian Lager dealt with the Commission's attempt to balance the right of one person to have access to information held by the Commission against the rights of other persons to protection of their personal privacy and data.

80 See particularly, Anne Peters, 'The European Ombudsman and the European Constitution', CMLRev. 42 (2005) 697-743 at 713-14.

${ }_{81}$ The mere fact that parallel investigatory procedures are underway before different bodies need not lead to the termination or suspension of any given enquiry. It could, however, provide an opportunity for this, but only if that is consistent with the statutory obligations of the body concerned. Given that sensitive matters and information are likely to be recorded in any such registry, management thereof is probably best left to a small inter-authority committee, which is itself subject to strict confidentiality obligations.

${ }_{82}$ Andreas Hamers, Der Petitionsausschuss des Europäischen Parlaments und der Europäische Bürgerbeauftragte - zu den außergerichtlichen Beschwerdeeinrichtungen der Europäischen Gemeinschaft (Pfaffenweiler: Centaurus 1999) 268. 


\section{The Ombudsman and the Integrated European Administration}

One central problem to ombuds-review in the EU was already on the policy making agenda at the time of the creation of the EO: the problems of integrated multilevel administration in the EU. Although final decisions are either adopted by an EU body or by a body under national law, Member States authorities are in various cases authorized to apply EU law (e.g., in the field of competition law under Articles 101 and 102 TFEU). In fact, it is rare that the implementation of EU policy areas is organised in a way which does not involve some form of composite decision-making procedures. These are procedures in which EU and Member State administrations cooperate in preparation of the formal adoption of a final decision either on the national or the European level. With regard to allocating powers to address maladministration, this distinction of supervisory levels in the face of integrated administrative procedures is highly problematic.

As discussed earlier, when the Spanish government made its proposal in the drafting of the Treaty of Maastricht it was already acutely aware of this set of problems and had, as one of several alternative approaches, provided for the possibility of the EO to review action of Member State administrations acting in the scope of EU law. ${ }^{83}$ But the mandate of the EO as introduced by the Treaty of Maastricht, now embodied in Article 228 TFEU, is more narrow: it only refers to the activities of 'Union institutions, bodies, offices or agencies' ${ }^{84}$

EO Söderman, at the very outset of his term, recognized the lacunae created by his limited mandate; thus, he called for the organization of a network of national and regional ombudsmen (including the EO) to provide mutual support and the exchanges of views among its members. The resulting network (now known as the European Network of Ombudsmen, or just the 'Network'), improves the overall ability to supervise administrative activity concerning EU law throughout the Union. ${ }^{85}$ For example, the Network provides the EO with the

83 Carlos Moreiro González, 'The Spanish Proposal to the Intergovernmental Conference on Political Union', in The European Ombudsman (ed.), The European Ombudsman, Origins, Establishment, Evolution, Office for Official Publications of the European Communities (Luxembourg: 2005) 27-37, at p. 34 and Annex II at p. 249.

${ }^{84}$ As previously mentioned, Article 228 TFEU's mandate specifically excludes the CJEU when acting in its judicial capacity.

${ }^{85}$ For a more detailed discussion, see Carol Harlow and Richard Rawlings, 'Promoting Accountability in Multi-Level Governance: A Network Approach', 
opportunity to transfer inadmissible complaints he or she receives to the relevant national or regional ombudsmen (and vice versa), so that those complaints can be handled by the ombudsman that actually oversees the administrative body responsible for the alleged maladministration. According to the EO's office:

The European Network of Ombudsmen consists of over 95 offices in 36 European countries. The Network includes the national and regional ombudsmen and similar bodies of the Member States of the European Union, the candidate countries for EU membership, and other European Economic Area countries, as well as the European Ombudsman and the Committee on Petitions of the European Parliament. The national ombudsmen and similar bodies in the Network have each appointed a liaison officer to act as a point of contact for other members of the Network. ${ }^{86}$

In addition to transferring cases, Network members seek and offer advice, exchange information, and coordinate activities and investigations. Nonetheless, and notwithstanding such cooperation, the strict, organic distinction of every ombudsman's competence can still lead to difficult situations, particularly when complaints emerge from what are commonly known as 'composite administrative procedures' (i.e., forms of highly integrated, administrative-procedural activities in which national and EU actors cooperate to implement EU policies) ${ }^{87}$ The use of such composite administrative procedures across a number of policy areas underscores the existing gaps or divergences among functionally different aspects of administrative organization. Unlike administrative decisionmaking network structures, supervisory and accountability mechanisms still mostly follow the traditional bifurcated system comprised of separate and distinct national and European levels.

The EO's oversight (i.e., limited to activities by EU-level entities) uses a traditionally organized supervisory structure that has difficulty allocating responsibility for procedural errors and finding adequate remedies for maladministration within such cooperative networks. The structure also has difficulty coping with the fact that the typical substantive cooperation in composite administrative procedures is the joint gathering and subsequent sharing of information. Thus, due to the EO's limited mandate and the

European Governance Papers No. C-06-02, 19-27 (www.connex-network.org/ eurogov/pdf/egp-connex-C-06-02.pdf, accessed 19 February 2010).

86 See www.ombudsman.europa.eu/en/atyourservice/enointroduction.faces, accessed 16 March 2016.

87 Herwig C.H. Hofmann, Gerard C. Rowe and Alexander Türk, Administrative Law and Policy of the EU (Oxford University Press 2011) 928-36. 
bifurcated nature of the supervisory system it contemplates, the EO's can only informally rely on the activities of national and regional ombudsmen throughout the Member States.

To address these problems, the Network devised a procedure through which national and regional ombudsmen can ask the EO to provide written answers to queries about European law, its interpretation, and its application to special cases. The EO either answers the questions him- or herself or, if appropriate, transmits the queries to the appropriate EU institution. ${ }^{88}$ This so-called query procedure allows national ombudsmen to obtain information and clarification about how the EO understands and interprets EU law generally or in relation to particular complaints. ${ }^{89}$ The latter can be important because national ombudsmen from Member States typically have a duty to review administrative activity in the implementation of EU law, which includes to ensure that substantive and procedural rights arising under EU law are fully respected within their national legal systems. The speed of the EO's response will, of course, be of the essence whenever such queries are received, which might not be feasible if the EO must frequently seek expert input by EU institutions (e.g., the Commission) and agencies.

Another manner to overcome problems arising from the EO's limited mandate is to participate in joint or parallel investigations. An example of this approach can be found in the EO's own-initiative investigation, $\mathrm{OI} / 9 / 2014 / \mathrm{MHZ}$, undertaken in cooperation with her national counterparts. The investigation concerned alleged types of maladministration in the context of the conduct of 'joint return operations' of immigrants to countries outside of the EU by the European agency in charge of border protection, FRONTEX, together with national authorities.

In her 2016 note entitled 'Reforming the European Network of Ombudsmen' the EO recently highlighted the benefits of parallel investigations seeing them as a key tool for advancing ombuds-review in an integrated European legal system with exchanges of information about pending allegations of maladministration, coordinated investigations into such allegations, and exchanges of investigative results, as well as coordinated procedural steps are indispensable in this context. Nonetheless, there appears to still be quite a bit of room for improvement in systematizing and formalizing cooperation mechanisms within the Network. If this cooperative Network approach were expanded, at least

88 The European Ombudsman, Annual Report 2006, 129.

89 Nikiforos Diamandouros, 'The European Ombudsman and the application of EU law by the Member States', Review of European Administrative Law 2 (2008) 5-37, at 26-7. 
in policy areas with composite administrative procedures, the resulting coordinated ombuds-review would become a much more relevant form of citizenry protection than recourse to the CJEU. As everyone knows, its judicial review only has a one-way reference procedure ${ }^{90}$ and certainly no possibility for coordinated action by the EU and national courts.

\section{The Accountability and Supervision of the European Ombudsman}

Supervisory authorities must, themselves, be subject to a certain amount of oversight and control to ensure their own accountability; they cannot, under the principles of democracy and the rule of law, be accountable to no one. Not surprisingly, the EO is primarily accountable to the Parliament, who exercises control through parliamentary supervision; ultimately, like every other EU institution or body, the EO can be held accountable by the CJEU. The CJEU's General Court has already exercised such judicial oversight, ruling on actions for damages brought against the EO pursuant to Article 340 TFEU. It has awarded damages for violation of procedural standards in cases of manifest error in the performance of the EO's duties when such error had a causal link to harm suffered by an individual that was subject to review under the criteria of Article 340, second paragraph TFEU (Article 288, second paragraph EC) in respect of an action for damages. ${ }^{91}$ The type of unlawful acts that the Court has reviewed includes matters such as distortion of facts, failure to exercise diligence in duties of inquiry, and a violation of the obligation to act within reasonable time. ${ }^{92} \mathrm{It}$ is fitting that a body in charge of reviewing those same criteria in connection with others has been held to the exact same standards in the exercise of its functions. In that case, the Court ordered the EO to pay nonpecuniary damages for its violation of those principles. ${ }^{93}$ Additionally, although initially pre-Lisbon, an action for failure to act was dismissed by that Court because it found that the EO was not an institution, ${ }^{94}$ under

\footnotetext{
$90 \quad$ Article 267 TFEU.

91 Case C-234/02 P European Ombudsman v Lamberts [2004] ECR I-2803, paras. 31-70; Case T-209/00 Lamberts v European Ombudsman [2002] ECR II-2203, paras. 45-60. For further reading, see Peter Gjerloeff Bonnor, 'The European Ombudsman: a novel source of soft law in the European Union', ELRev. 25 (2000) 39-56.

${ }_{92}$ T-217/11 Claire Staelen v European Ombudsman of 29 April 2015, para. 336.

93 T-217/11 Claire Staelen v European Ombudsman of 29 April 2015, para. 336 establishing the damages ex aequo et bono.

94 On the basis of former Article 232 EC; see, e.g., Case T-103/99 Associazione delle cantine sociali venete $v$ European Ombudsman and European Parliament (ACSV) [2000] ECR II-4165.
} 
Article 265 TFEU the review now extends to omissions to all 'bodies, offices and agencies of the Union' including the EO. Actions against the EO for annulment under Article 263 TFEU or failure to act under Article 265 TFEU are, subject to the limitations otherwise stated in the TFEU, admissible. ${ }^{95}$ The Court might also be called on to rule on the limits of ombuds-review and, thus, have an opportunity to provide its definitive, judicial interpretation of the concept of maladministration.

\section{ASSESSMENT: THE OMBUDSMAN AS 'INTEGRITY'-BODY}

This chapter outlined the constitutional mandate and legal framework of the EO with a view towards assessing future possibilities of ombudsreview within the EU. The EO is an alternative to judicial review ensuring that EU citizens and others residing in the Union can enjoy, to the fullest, their rights arising from the Treaties and Union law whilst being served by, as Article 298 TFEU now expresses, an 'open, efficient and independent European administration' ${ }^{96}$ By contrast to judicial review, ombudsreview commands no binding authority. Rather, the EO must rely on his or her powers of persuasion, in the form of publicized investigations of, and critical remarks or recommendations directed at, recalcitrant EU institutions, bodies, offices, and agencies, which are intended to 'name and shame' them because such critical remarks and recommendations are, to the extent permitted by law, made public. Also, to undertake his or her investigatory functions, the EO must often depend, at least to some extent, on the cooperation of the very Union institutions or bodies it is investigating. If the institution or body refuses to address any maladministration the EO finds, the EO must depend on the Parliament to take heed of his or her reports and actually follow up on unremediated maladministration.

The EO expands possible avenues of individual redress and stimulates systematic redress of administrative (mal)practice, but does so from a position of relative weakness. Independence and impartiality can thus be counted as amongst the EO's most powerful attributes. Arguably, it is the EO's ultimate lack of hard power - from a legal, rather than a moral or political point of view - that supplies his or her capacity to achieve positive results in a relatively simple and efficient way, even though the EO can never guarantee success. Maintaining what can be broadly referred to as

\footnotetext{
95 See, e.g., C-535/12 P Olatra v European Ombudsman of 6 June 2013.
}

96 Article 298 TFEU. 
systemic 'integrity', as opposed to a purely legal review, is characteristic of bodies that are neither directly linked to any of the three 'classic' branches of power such as the EO. The EO's contribution to maintaining the 'integrity' of decision-making through their persuasive powers and their ability to raise public exposure and awareness through their reports and decisions. It is in these contexts that the EO occupies a unique position.

By handling individual complaints and basing proposals on real life cases, the the EO gains legitimacy, public standing and respect from the EU's institutions. The EO's mediation role in resolving complaint based cases in which the wrong becomes evident in an individual situation, leads increased compliance by EU institutions with the suggestions made by the EO. A high rate of compliance, if visibly achieved, can give credibility to the EO way of solving problems even in the absence of legally binding solutions and potential payments of damages. The decisive weakness of the complaint-based system of initiating ombuds-review, however, is that it is dependent on a high level of awareness among the European citizenry. Only if the citizens which can be affected of maladministration know of the existence, accessibility, and potential power of the EO as an institution, will they enter complaints. In that regard, more effort might be made by all EU institutions, bodies, offices, and agencies to promote the role of the EO. It might be unrealistic to expect the EU administration to embrace that task with great enthusiasm.

This is where the use of own-initiative investigations by the EO might have a place to raise awareness of the EO. They do however most good in cases where the individuals most affected by maladministration have no realistic chance of lodging a complaint, such as occurred in the case of refugees facing joint return operation administered by FRONTEX ${ }^{97}$ The EO's own-initiative investigations can also be a very helpful tool when the number of individual complaints indicates the existence of systemic problems in a certain field.

However, a systematic use of own-initiative investigations into fields the EO identifies as problematic (based on his or her own convictions rather than the volume of individual complaints) would require further scrutiny as to whether the advantages of such an approach outweigh the potential disadvantages. Potential constraints have to be weighed when devising techniques that would allow the EO to reach the highly ambitious goal of ensuring integrity and accountability within the Union's executive branch. Here, the EO would face a significant risk of being accused of

\footnotetext{
97 See the Ombudsman's own-initiative inquiry OI/9/2014/MHZ regarding
} types of maladministration in the context of FRONTEX. 
being politically motivated and acting indiscriminately, based on his or her own political agenda. The EO might even run the risk of being pulled into existing inter-institutional conflicts, which would be highly detrimental to his or her independence (or just the perception of his or her independence) and, thus, his or her impartiality. The risks of engaging in investigations that could result in a loss of status as an independent mediator between citizens and the EU administration must, therefore, be very carefully evaluated.

The big question, then, is whether taking on a decidedly political role limits, in effect, the EO's ability to conduct impartial enquiries, which is the basis of the EO's independence. Does taking on a more political role actually endanger the EO or risk accusations that the EO is just another policy 'entrepreneur'? If one accepts that the basis for the respect and legitimacy offered to the EO is his or her impartial mediating role and problem-solving capacity, the risks of undertaking a more political role are quite real. If, on the other hand, the EO's central problem is the public's lack of awareness of the existence of the EO, then headlinegrabbing, politically sensitive investigations, which no other actors are able to undertake, may be an important tool in the EO's repertoire. ${ }^{98}$ 2016.

98 See, e.g., European Ombudsman, Case OI/6/2016/AB opened on 26 May 